\title{
System Reveos w świetle innych metod rozdziału krwi pełnej na składniki - porównanie badań kontroli jakości
}

\author{
Reveos system in the light of other methods of separation of whole blood \\ into components - comparison of quality control tests
}

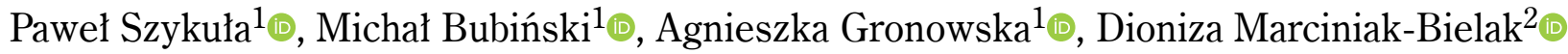

${ }^{1}$ Dział Preparatyki Regionalnego Centrum Krwiodawstwa i Krwiolecznictwa w Łodzi

${ }^{2}$ Zastępca Dyrektora ds. medycznych Regionalnego Centrum Krwiodawstwa i Krwiolecznictwa w Łodzi

Streszczenie

Wstęp. Jednym z elementów sktadajacych się na bezpieczeństwo krwi jest automatyzacja procesu preparatyki krwi petnej konserwowanej (KPK) w celu uzyskania poszczególnych sktadników. W 2017 roku w Regionalnym Centrum Krwiodawstwa i Krwiolecznictwa (RCKiK) $w$ Lodzi wprowadzono system Reveos, który dzięki potaczeniu funkcji wirówki $i$ prasy zapewnia petna automatyzacje procesu rozdziatu KPK, minimalizujac ryzyko btędu ludzkiego, poprawiajac tym samym doktadność i powtarzalność.

Cel. Porównanie wyników kontroli jakości sktadników krwi otrzymanych po rozdziale KPKza pomoca pras Compomat G5 i Optipress II oraz systemu Reveos. Porównanie stopnia spetnienia zaleceń dotyczqcych jakości sktadników krwi zawartych w obowiqzujacych przepisach.

Materiały i metody. Rozdzielono na sktadniki 150 jednostek KPK, wykorzystujac w/w systemy, oznaczajac wybrane parametry.

Wyniki. Oznaczono odpowiednio dla Compomat, Optipress $i$ Reveos parametry:

—osocza: objętość (V) $260 \pm 13 \mathrm{ml}, 262 \pm 14 \mathrm{ml}$ i $239 \pm 20 \mathrm{ml}$, krwinki plytkowe (PLT $\times$ $\left.10^{9} / l\right): 16,23$ i 23 l, erytrocyty $<6 \times 10^{6} / l$, leukocyty $<0,1 \times 10^{9} l$;

—KKCz: objętość $(V): 286 \pm 13 \mathrm{ml}, 272 \pm 13 \mathrm{ml}$ i $295 \pm 17 \mathrm{ml}$, hemoglobina (Hb: g/jedn): 55, 51, 58, hematokryt (Ht, \%): 59, 58 i 52 leukocyty (WBCs $\times 10^{9}$ /jedn.) 0,6; 0,6; 0,1.

- objętość kożuszków wynosita (V) 56,6 ml i 56,1 ml dla Compomat i Optipress, a objętość TKKP (tymczasowy koncentrat krwinek plytkowych, IPU - Interim Platelet Unit) $z$ systemu Reveos wynosita $37,8 \mathrm{ml}$.

— zawartość krwinek plytkowych w kożuszkach z pras i TKKP wynosita odpowiednio 0,8, 0,7, $0,66 \times 10^{11} / j e d n$.

Wnioski. Porównanie jakości sktadników po rozdziale KPK wykazato niewielkie rózinice $w$ oznaczanych parametrach. Gtówna różnica dotyczy objętości otrzymanego osocza i $\mathrm{KKCz} /$ /UKKCz. Pomimo tego wszystkie otrzymane sktadniki spetniaty parametry kontroli jakości, a metody rozdziatu $z$ powodzeniem moga być wykorzystywane $w$ rutynowej pracy. System Reveos pozwala na uzyskanie jakościowo dobrych sktadników podczas jednoetapowego procesu. Zmniejsza to ingerencje personelu $w$ caty proces, co może skutkować minimalizacja bledów

Adres do korespondencji: dr n. biol. Paweł Szykuła, Regionalne Centrum Krwiodawstwa i Krwiolecznictwa w Łodzi, ul. Franciszkańska 17/25, 91-433 Łódź, tel. 664139 741, e-mail: pajo13@wp.pl 
podczas przetwarzania KPK.

Słowa kluczowe: Compomat G5, Optipress II, Reveos

J. Transf. Med. 2019; 12: 47-55

\begin{abstract}
Introduction. One of the key elements of blood safety is automated whole blood processing. The Regional Blood Transfusion Center (BC) in Eódź had the Reveos system installed in 2017. By combining centrifugation and fractionation press, the Reveos system provides full automation of whole blood processing so it minimizes the risk of human error and ensures more accuracy and repeatability.

The study aim is was determine and compare the quality control parameters of blood components obtained with Compomat G5, Optipress II and the Reveos system as well as to compare the level of compliance with current quality requirements and recommendations.

Materials and methods. 150 units of whole blood were processed into blood components using the 3 above mentioned systems. Selected parameters were determined.

Results. The following parameters were determined for blood components obtained with Compomat, Optipress and Reveos respectively:

- plasma: volume $260 \pm 13 \mathrm{ml}$, $262 \pm 14 \mathrm{ml}$ and $239 \pm 20 \mathrm{ml}$, platelets: 16,23 and $23 \times$ $10^{9} / \mathrm{l}$, red blood cells $<6 \times 10^{6} / \mathrm{l}$, leukocytes $<0,1 \times 10^{9} \mathrm{l}$;

— red blood cells (RBCs): volume $286 \pm 13 \mathrm{ml}, 272 \pm 13 \mathrm{ml}$ and $295 \pm 17 \mathrm{ml}$, hemoglobin 55, 51 and $58 \mathrm{~g} /$ unit., hematocrit 59, 58 and $52 \%$, leukocytes $(W B C)-0,6 \times 10^{9} /$ unit., $0,6 \times 10^{9} /$ unit. and $0,1 \times 10^{6} /$ unit;

- buffy coat: volume: $56,6 \mathrm{ml}$ and $56,1 \mathrm{ml}$; platelet count -0.8 and $0.7 \times 10^{11} /$ unit for Compomat and Optipress respectively;

— interim platelet volume - 37,8 ml; platelet count - $0.66 \times 10^{11} /$ unit.
\end{abstract}

Conclusions. Slight differences were reported for the parameters of the blood components processed using the 3 systems. The main difference was observed with regard to the volume of plasma and RBCs/leukoreduced RBCs. Nevertheless, all blood components met quality control requirements. All the 3 processing systems can therefore be recommended for routine use. The Reveos system delivers high quality blood components in a one-step process with limited participation of blood center staff, which minimizes the risk of human errors.

Key words: Compomat G5, Optipress II, Reveos

J. Transf. Med. 2019; 12: 47-55

\title{
Wstęp
}

Aktualnie rozdział krwi pełnej konserwowanej (KPK) na składniki opiera się głównie na dwuetapowych metodach wirowania $z$ wykorzystaniem pras automatycznych, które opisano już w latach 80 . XX wieku $[1,2]$. Prasy te pozwalają na standaryzację otrzymywanych składników krwi znacznie lepszą niż w przypadku pras manualnych, ponieważ nowoczesne urządzenia są wyposażone w czujniki optyczne, które automatycznie sterują procesem ich przepływu do odpowiednich pojemników odbiorczych. Po zakończeniu procesu rozdziału krwi składniki są automatycznie ważone, a dane o przebiegu procesu przesyłane do systemu teleinformatycznego stosowanego w centrum krwiodawstwa i krwiolecznictwa. W przypadku rozdziału KPK przy użyciu pras automatycznych najczęściej otrzymujemy: koncentrat krwinek czerwonych pozbawiony kożuszka leukocytarno- 


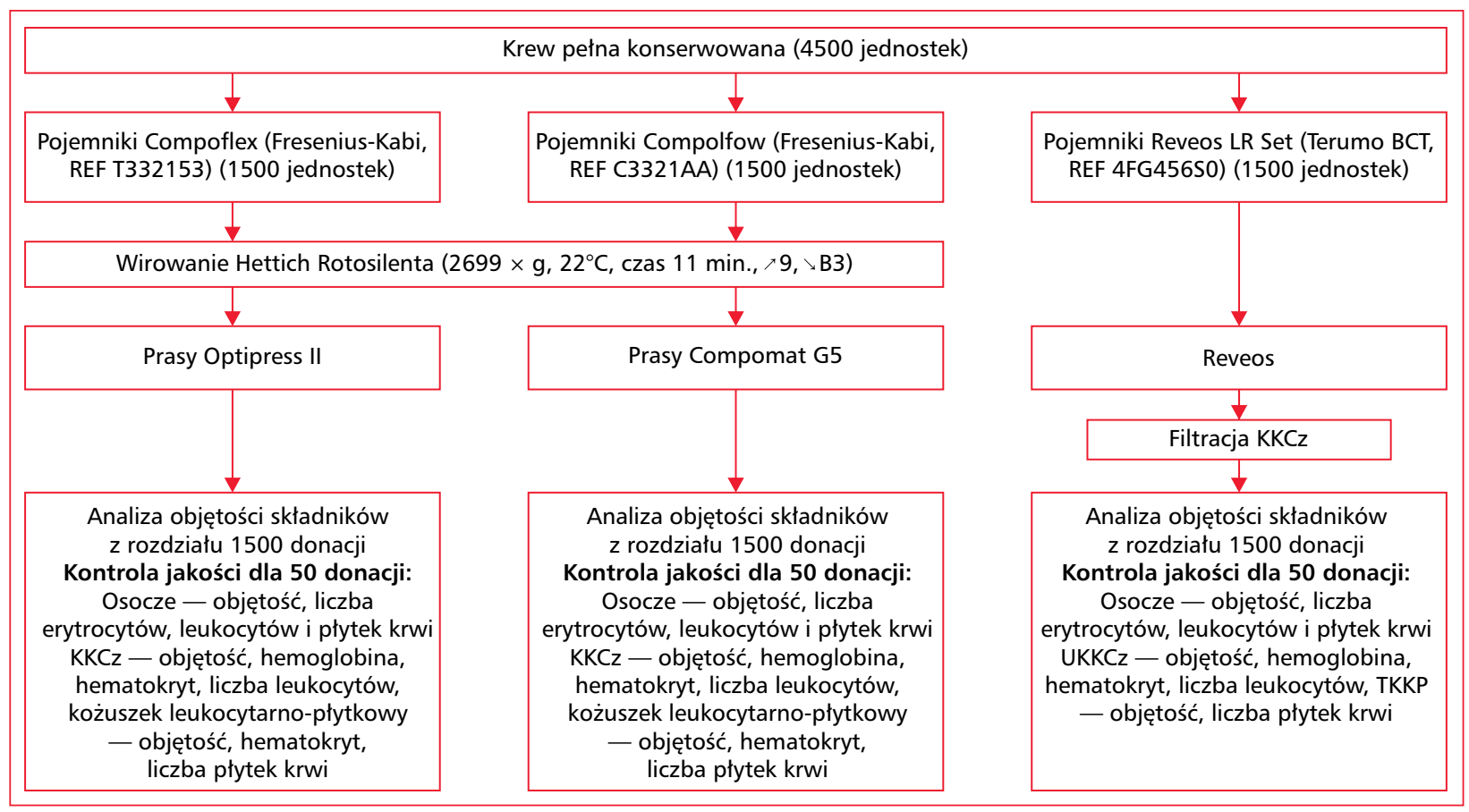

Rycina 1. Preparatyka KPK przy użyciu pras: Optipress II, Compomat G5 oraz systemu Reveos

Figure 1. Flow chart of whole blood processing with Optipress II, Compomat G5 and Reveos

-płytkowego (KKCz bez koż. L.-pł.), osocze i kożuszek leukocytarno-płytkowy.

Dwa główne powody wprowadzania automatyzacji procesu otrzymywania składników krwi to po pierwsze, duża objętość krwi do przetworzenia (automatyzacja zwiększa wydajność procesu), po drugie, możliwość uzyskania składników o określonych parametrach jakościowych [3]. W RCKiK w Łodzi w 2012 roku metodę rozdziału KPK opartą na pojemnikach „góra-góra” (prasy manualne) całkowicie zastąpiono systemem rozdziału opartym na metodzie $z$ zastosowaniem pras automatycznych Optipress II (Fenwal) i KPK pobranej do pojemników „góra-dół” . W 2017 roku prasy te zostały zastąpione nowego typu urządzeniami (prasami) Compomat G5 (Fresenius-Kabi). Równocześnie wprowadzono do stosowania system Reveos (Terumo BCT).

System Reveos stanowi połączenie wirówki i prasy do rozdziału KPK. Każde urządzenie jest wyposażone w sterowaną systemem informatycznym wirówkę $z$ rotorem, który zawiera 4 miejsca do rozdziału KPK. Każde $z$ tych miejsc stanowi osobną prasę hydrauliczną pracującą w trakcie wirowania KPK. W pełni zautomatyzowane urządzenie Reveos umożliwia jednoczesne wirowanie i rozdział 4 jednostek krwi w jednej procedurze. Zestawy do pobierania i rozdziału KPK są wyposażone w filtr antyleukocytarny, co umożliwia otrzymanie, w wy- niku jednego cyklu, 4 jednostek UKKCz/RW (ubogleukocytarny koncentrat krwinek czerwonych $z$ roztworem wzbogacającym), 4 jednostek osocza oraz 4 jednostki TKKP. Jednostki TKKP zawierają osocze, krwinki płytkowe i leukocyty pochodzące $z$ jednej donacji krwi, stanowiąc tym samym osobną klasę preparatów i nie mogą być traktowane jak kożuszek leukocytarno-płytkowy.

Celem pracy była ocena jakości składników krwi otrzymanych $z$ systemu Reveos oraz ich porównanie $z$ wynikami otrzymanymi $z$ wykorzystaniem pras automatycznych Compomat G5 i Optipress II. Ponadto sprawdzono, czy uzyskane wyniki spełniają zakresy normy parametrów kontroli jakości składników krwi zwartych w Obwieszeniu Ministra Zdrowia z 6 marca 2019 roku [4].

\section{Material i metody}

Krew pełną (450 $\mathrm{ml} \pm 10 \%)$ pobierano od zdrowych dawców w RCKiK w Łodzi, a następnie poddano leżakowaniu $\mathrm{w}$ temperaturze $20-24^{\circ} \mathrm{C}$ przez minimum 2 godziny. Jako antykoagulant zastosowano roztwór CPD (cytrynian, fosforan, glukoza). Preparatyka 4500 jednostek krwi pełnej odbywała się w Dziale Preparatyki. Schemat badania przedstawiono na rycinie 1 .

$Z$ programów obsługujących urządzenia zebrano informacje dotyczące objętości uzyskanych skład- 

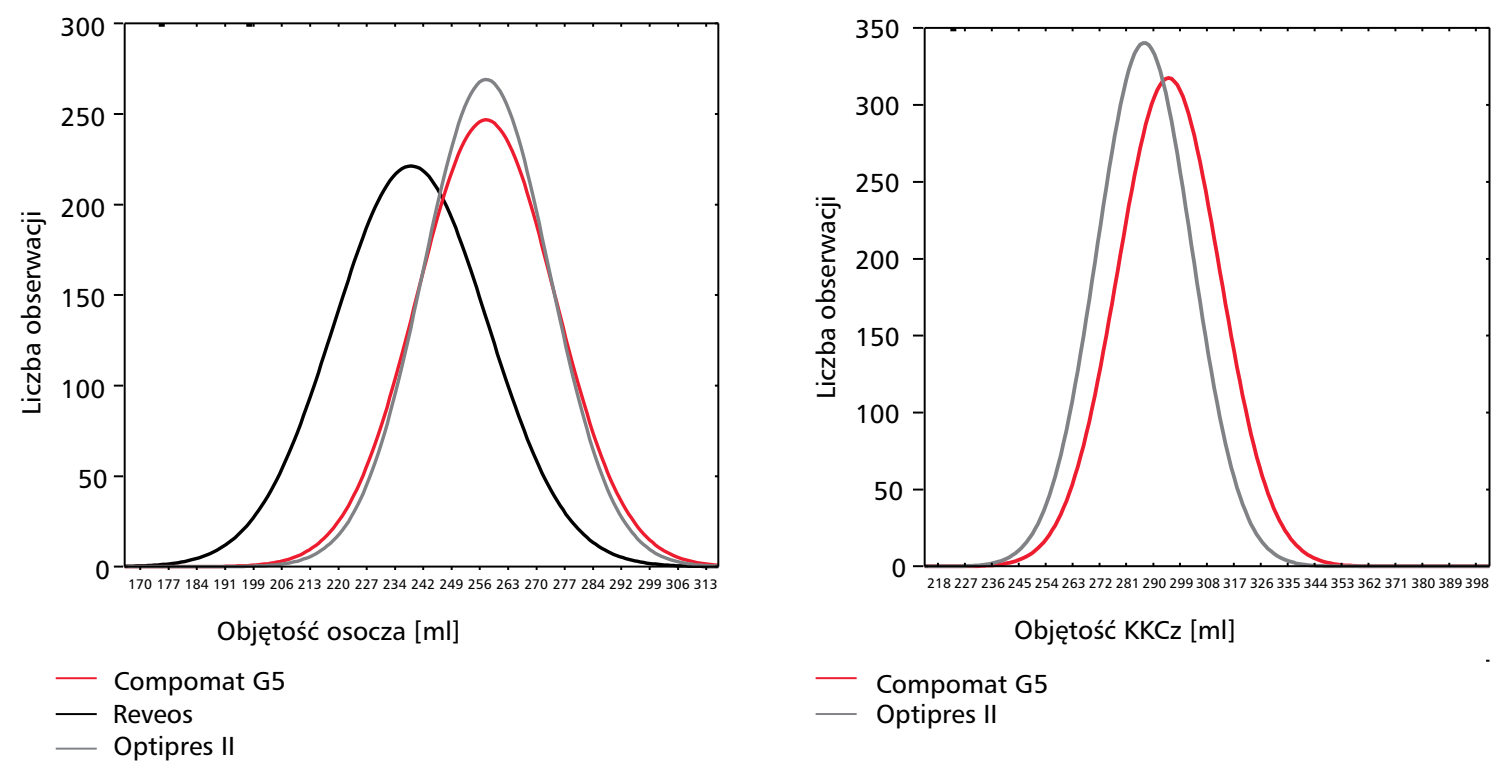

Rycina 2. Histogram objętości osocza i KKCz uzyskanego za pomocą urządzenia Reveos oraz pras Compomat G5 i Optipres II

Figure 2. Histogram of plasma and red blood cells volume obtained with the Reveos device, Compomat G5 and Optipres II presses
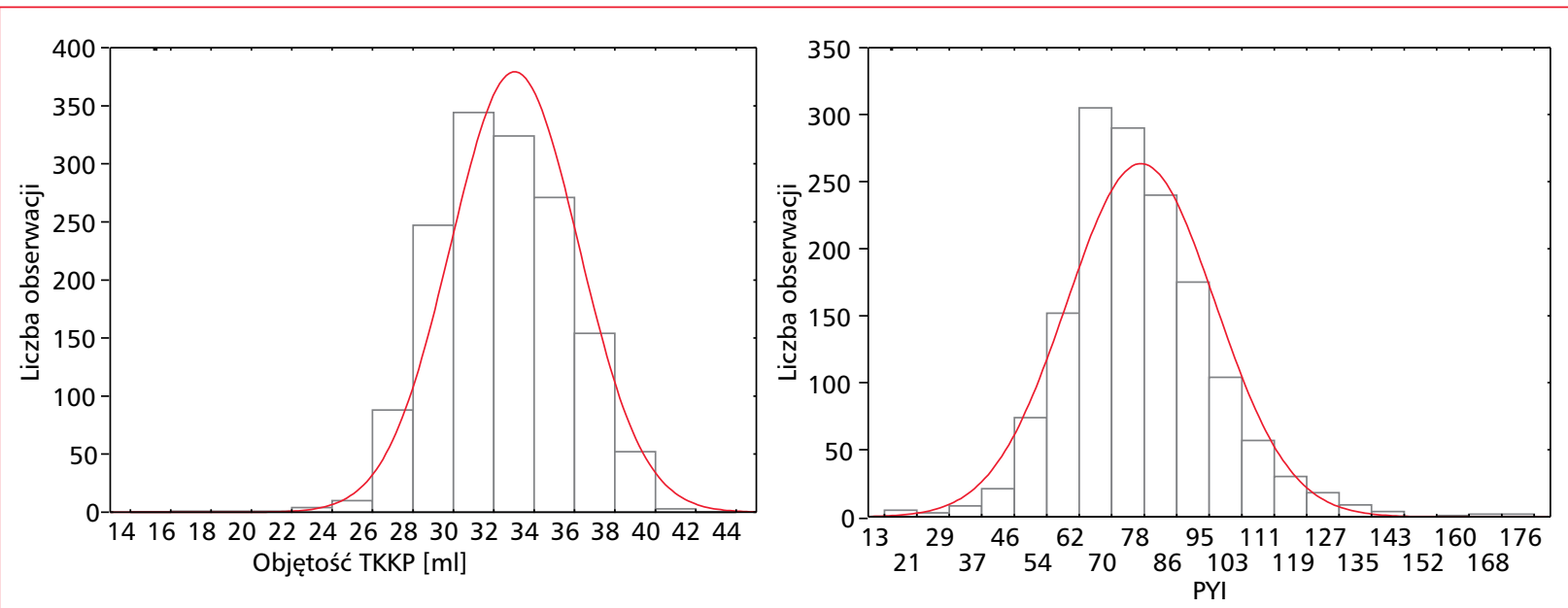

Rycina 3. Rozkłady objętości i wartości indeksu płytkowego (PYI) TKKP uzyskane za pomocą urządzenia Reveos i przedstawione w postaci histogramów

Figure 3. Distribution of volume and index values of a plate index (PYI) TKKP obtained with the Reveos device presented as histograms

ników. Dane zaprezentowano w postaci histogramu (ryc. 2, 3). Do kontroli jakości pobrano próbki pochodzące $z 50$ losowo wybranych jednostek krwi dla każdej $\mathrm{z}$ metod preparatyki. Próbki osocza, $\mathrm{KKC} z$ i kożuszków leukocytarno-płytkowych zostały pobrane natychmiast po otrzymaniu składników. Natomiast
TKKP leżakowano w temperaturze $20-24^{\circ} \mathrm{C}$ przez jedną godzinę, a następnie przenoszono do cieplarki $\left(20-24^{\circ} \mathrm{C}\right)$, gdzie były wytrząsane (60 cykli/min) do następnego dnia.

\section{Wyniki}


Tabela 1. Zestawienie wartości średnich objętości KKCz, UKKCz i osocza uzyskanych w wyniku rozdziału KPK $\mathrm{z}$ trzech porównywanych systemów ( $\mathrm{n}=1500$ dla każdego systemu)

Table 1. Comparison of mean volumes of RBCs, leukodepleted RBCs s and plasma obtained with the 3 systems ( $n=1500$ for each system)

\begin{tabular}{|c|c|c|c|c|c|c|}
\hline & \multicolumn{2}{|c|}{ Reveos } & \multicolumn{2}{|c|}{ Compomat G5 } & \multicolumn{2}{|c|}{ Optipress II } \\
\hline & \multicolumn{6}{|c|}{$\mathrm{V}(\mathrm{ml})$} \\
\hline & UKKCz & Osocze & $\mathrm{KKCz}$ & Osocze & $\mathrm{KKCz}$ & Osocze \\
\hline Średnia & $x$ & 238 & 295 & 257 & 287 & 257 \\
\hline SD & $x$ & 19 & 17 & 17 & 16 & 16 \\
\hline CV [\%] & $x$ & 8 & 6 & 7 & 6 & 6 \\
\hline Min & $x$ & 170 & 218 & 204 & 220 & 189 \\
\hline Max & $x$ & 301 & 398 & 313 & 353 & 310 \\
\hline
\end{tabular}

Z programów komputerowych obsługujących urządzenia pobrano wyniki dotyczące rozdziału 1500 jednostek KPK dla każdego systemu. Dane dotyczące objętości osocza i $\mathrm{KKCz}$ przedstawiono w postaci krzywych rozkładu objętości na rycinie 2 .

Wartość średnią, odchylenie standardowe, współczynnik zmienności oraz wartość minimalną i maksymalną dla otrzymanych składników krwi zaprezentowano w tabeli 1.

Wykazano, że średnia objętość $\mathrm{KKCz}$ pochodzącego $z$ pras Compomat G5 jest niespełna 3\% większa niż $\mathrm{KKCz} z$ pras Optipress II. Różnica ta jest istotna statystycznie $(\mathrm{p}<0,00001)$. Nie wykazano różnic w średniej objętości osocza w przypadku KPK rozdzielanej przy użyciu pras Compomat G5 i Optipress II. Najmniejszą średnią objętość osocza uzyskano w przypadku urządzeń Reveos. Różnica w średniej objętości osocza otrzymanego $z$ urządzeń Reveos w porównaniu $z$ osoczem $z$ pras Compomat G5 i Opitpress II wyniosła $8 \%$ i była istotna statystycznie ( $\mathrm{p}<$ $<0,00001$ ) (tab. 1).

Wykonano oznaczenia parametrów kontroli jakości dla składników krwi uzyskanych po rozdziale 50 jednostek KPK dla każdej $z$ badanych metod. Wyniki oznaczeń zestawiono w tabelach 2 i 3 . W tabeli 2 przedstawiono ponadto kryteria jakościowe, jakie powinny spełniać otrzymane składniki oraz odsetek składników spełniających te kryteria. Wszystkie kryteria poza objętością pochodzą $z$ aktualnego obwieszczenia dotyczącego Krwiodawstwa w Polsce [4]. Zakresy objętości $\mathrm{KKCz}$ i osocza dla każdej metody zostały opracowane na podstawie wyników rutynowej kontroli jakości przez Dział Zapewnienia Jakości.

Różnica pomiędzy średnimi objętościami $\mathrm{KKC} z / \mathrm{RW}-$ bez koż. 1.-pł otrzymanego odpowied- nio z pras Compomat G5 i Optipres II uzyskanymi $\mathrm{w}$ badaniach kontroli jakości jest istotna statystycznie $(\mathrm{p}<0,00001)$. Kryteria akceptacji dla objętości $\mathrm{KKCz}$ zostały spełnione odpowiednio w $100 \%$ i $98 \%$. Objętość UKKCz/RW otrzymanego Z systemu Reveos wynosi $295 \pm 17 \mathrm{ml}$ (tab. 2).

Różnica pomiędzy średnią zawartością hemoglobiny $\mathrm{w} \mathrm{KKC} z / \mathrm{RW}$-bez koż. 1.-pł otrzymanego odpowiednio $z$ pras Compomat G5 i Optipres II jest istotna statystycznie $(\mathrm{p}<0,0001)$. Kryteria akceptacji dla zawartości hemoglobiny w składnikach czerwonokrwinkowych pochodzących $z$ systemu Reveos i z pras Compomat G5 zostały spełnione w $100 \%$. Natomiast dla $\mathrm{KKC} z / \mathrm{RW}-\mathrm{bez}$ koż. 1.-p1 otrzymanego $z$ pras Optipres II kryterium akceptacji dotyczące zawartości hemoglobiny zostało spełnione w $98 \%$ (tab. 2).

Nie wykazano natomiast statystycznie istotnych różnic w średnich wartościach hematokrytu i średniej liczbie leukocytów w KKCz/RW-bez koż. 1.-pł otrzymanych z pras Compomat G5 i Optipres II. Wszystkie składniki spełniały założone kryteria akceptacji. Średnia liczba leukocytów w obu przypadkach wynosiła $0,6 \pm 0,3 \times 10^{9} /$ jedn. Kryterium zawartości leukocytów spełniało $98 \%$ i $96 \%$ $\mathrm{KKC} z / \mathrm{RW}-$ bez koż. 1.-pł otrzymanych odpowiednio przy użyciu pras Compomat G5 i Optipres II.

Porównując objętość osocza, wykazano istotne statystyczne różnice pomiędzy składnikami otrzymanymi $z$ pras automatycznych a osoczami otrzymanymi $z$ urządzenia Reveos ( $<<0,00001)$. Kryteria akceptacji spełniało $92 \%$ jednostek osocza z urządzeń Reveos, $100 \%$ jednostek osocza $z$ pras Compomat G5 i 98\% jednostek osocza $z$ pras Optipres II. Kryteria akceptacji dotyczące zawartości krwinek płytkowych spełniało $94 \%$ osocza otrzymanego przy użyciu urządzenia Reveos, podczas gdy w przypadku pras było to $100 \%$. 


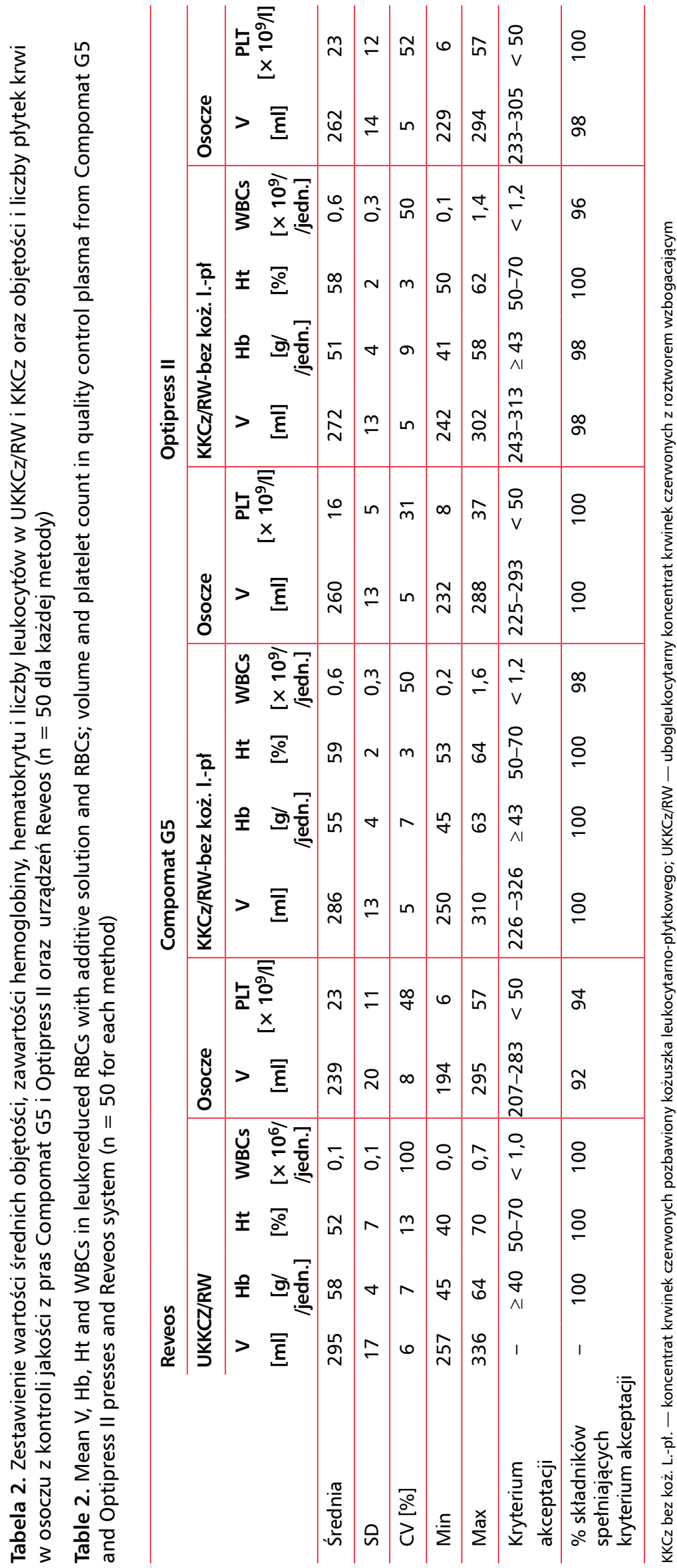


Tabela 3. Zestawienie wartości średnich objętości, hematokrytu oraz liczby krwinek płytkowych dla danych z kontroli jakości z systemu Reveos oraz pras Compomat G5 i Optipress II ( $\mathrm{n}=50$ składników)

Table 3. Mean volume, hematocrit and platelet count for quality control data from Reveos system and Compomat $\mathrm{G} 5$ and Optipress II presses ( $\mathrm{n}=50$ components).

\begin{tabular}{|c|c|c|c|c|c|c|c|c|}
\hline & \multirow{2}{*}{\multicolumn{2}{|c|}{$\begin{array}{c}\text { Reveos } \\
\text { TKKP }\end{array}$}} & \multicolumn{3}{|c|}{ Compomat G5 } & \multicolumn{3}{|c|}{ Optipress II } \\
\hline & & & & & Kożuszek leuk & tarno & tkow & \\
\hline & $\begin{array}{c}\mathrm{V} \\
{[\mathrm{ml}]}\end{array}$ & $\begin{array}{c}\text { PLT } \\
{\left[\times 10^{11} / \text { jedn. }\right]}\end{array}$ & $\begin{array}{c}\mathrm{V} \\
{[\mathrm{ml}]}\end{array}$ & $\begin{array}{c}\mathrm{Ht} \\
{[\%]}\end{array}$ & $\begin{array}{c}\text { PLT } \\
{\left[\times 10^{11 / j e d n .]}\right.}\end{array}$ & $\begin{array}{c}\mathrm{V} \\
{[\mathrm{ml}]}\end{array}$ & $\begin{array}{l}\mathrm{Ht} \\
{[\%]}\end{array}$ & $\begin{array}{c}\text { PLT } \\
{\left[\times 10^{11 / j e d n .]}\right.}\end{array}$ \\
\hline Średnia & 32,9 & 0,77 & 56,6 & 41,9 & 0,8 & 64,1 & 54 & 0,7 \\
\hline SD & 3,2 & 0,2 & 3,17 & 3 & 0,3 & 4,6 & 4,2 & 0,2 \\
\hline CV & 10 & 24 & 6 & 7 & 37 & 7 & 8 & 29 \\
\hline Min & 18 & 0,13 & 51 & 37 & 0,1 & 52 & 43 & 0,25 \\
\hline Max & 41 & 1,76 & 65 & 50 & 1,4 & 72 & 76 & 1,03 \\
\hline
\end{tabular}

Analiza zawartości erytrocytów i leukocytów w osoczu wykazała, że wszystkie składniki otrzymane za pomocą analizowanych metod rozdziału spełniały założone kryteria w $100 \%$. Zawartość erytrocytów nie przekraczała $6 \times 10^{9} / 1$, a leukocytów $0,1 \times 10^{9} / 1$.

Na rycinie 3 przedstawiono histogramy objętości i wartości indeksu płytkowego (PYI) TKKP uzyskanego przez zestawienie 1500 pomiarów otrzymanych $z$ systemu Reveos.

Porównano średnie objętości i średnie wartości hematokrytu kożuszków leukocytarno-płytkowych pochodzących z pras Optipress II i Compomat G5 (tab. 3). Wykazano, że zarówno średnia objętość, jak i hematokryt kożuszka leukocytarno-płytkowego są większe po rozdziale KPK przy użyciu pras Optipress II odpowiednio o $12 \%$ i $22 \%$ w porównaniu $z$ prasami Compomat G5. Różnice te są istotne statystycznie ( $<$ 0,00001) (tab. 3).

Różnice pomiędzy średnią liczbą płytek krwi w kożuszkach otrzymanych przy użyciu pras nie są istotne statystycznie. Średnia objętość TKKP oznaczona w wyniku kontroli jakości 50 składników wynosi $32,9 \mathrm{ml} \pm 3,2$, średnia liczba płytek krwi wynosi $0,77 \pm 0,2 \times 10^{11} /$ jedn. (tab. 3 ).

\section{Dyskusja}

Rozdział krwi pełnej na składniki może być wykonany za pomocą kliku metod. Obecnie wykorzystywane metody charakteryzują się dużą automatyzacją procesu, a w konsekwencji także dużą powtarzalnością uzyskiwanych wyników. $\mathrm{W}$ pracy porównano 3 metody rozdziału krwi pełnej na składniki, które są lub były rutynowo wykorzystywane w RCKiK w Łodzi. Celem pracy była ocena jakości składników otrzymanych $z$ systemu
Reveos oraz porównanie wyników kontroli jakości składników krwi otrzymanych $z$ systemu Reveos $z$ wynikami rozdziału KPK na składniki z wykorzystaniem pras automatycznych.

W niniejszej pracy zaobserwowano, że osocze otrzymane przy zastosowaniu systemu Reveos charakteryzuje się mniejszą średnią objętością niż osocze otrzymane $z$ pras automatycznych. Różnica w średnich objętościach osocza wynosi $8 \%$ i jest widoczna zarówno w danych pobranych bezpośrednio $z$ urządzeń $(p<0,00001)$, jak i wyników badań kontroli jakości ( $p<0,0001)$. Johnson i wsp. nie zaobserwowali istotnej różnicy w średniej objętości osocza pochodzącego z systemu Reveos i pras Optipress II [5]. Różnica w wynikach może być wytłumaczona rozbieżnością w procedurze przygotowania krwi pełnej do rozdziału. W przypadku cytowanej pracy KPK była przechowywana przez noc $\mathrm{w}$ temperaturze $20-24^{\circ} \mathrm{C}$ i poddawana preparatyce dopiero następnego dnia. Na końcową objętość osocza w przypadku systemu Reveos wpływa także objętość TKKP uzyskiwanego w procesie rozdziału. Im większą objętość TKKP użytkownik chce uzyskać, tym mniejsza będzie końcowa objętość osocza. Inaczej jest w przypadku zwiększania objętości kożuszka leukocytarno-płytkowego w przypadku pras. Zwiększenie objętości kożuszka, przy zachowaniu stałej wartości hematokrytu, odbywa się kosztem zmniejszenia objętości zarówno osocza, jak i KKCz. Obowiązujące dla osocza normy jakościowe dotyczące liczby leukocytów i erytrocytów zostały spełnione zarówno przez składniki otrzymane $z$ systemu Reveos, jaki i pras automatycznych. Legerberg i wsp. porównali osocze pochodzące $z$ systemu Reveos, przetworzone zarówno bezpośrednio po pobraniu, jak i po całonocnym leżakowaniu KPK, dowodząc, 
że uzyskane za pomocą systemu Reveos zawiera mniejszą liczbę zanieczyszczeń spowodowanych erytrocytami i leukocytami niż osocze otrzymane $z$ pras automatycznych [6]. W przypadku osocza pochodzącego $z$ systemu Reveos w dwóch jednostkach zaobserwowano podwyższoną liczbę krwinek płytkowych.

Rozkład objętości osocza otrzymanego w systemie Reveos zdecydowanie różni się od rozkładu dla osocza $z$ pras. $Z$ analizy wynika, że osocze otrzymane $z$ systemu Reveos charakteryzuje się nie tylko mniejszą wartością średnią, ale także większym współczynnikiem zmienności. Tym niemniej wyniki analizy potwierdzają, że osocze otrzymane $z$ systemu Reveos spełnia obowiązujące kryteria i jest wysokiej jakości.

Wykazano, że średnia objętość $\mathrm{KKCz}$ pochodzącego $z$ pras Compomat G5 jest większa o około 3-5\% niż średnia objętość $\mathrm{KKC} z$ z pras Optipress II zarówno w przypadku analizy wyników otrzymanych bezpośrednio $z$ urządzeń, jak i wyników kontroli jakości. Bontekoe i inni autorzy również wykazali istotną statystycznie różnicę w objętości $\mathrm{KKCz}$ po leukoredukcji otrzymanego przy zastosowaniu tych samych urządzeń [7]. Autorzy dowodzą, że różnice te są na tyle niewielkie, że prawdopodobnie mogłyby być zniwelowane poprzez drobną zmianę $\mathrm{w}$ parametrach procesu rozdziału krwi przy użyciu prasy. Ponieważ ze względów technicznych niemożliwe jest uzyskanie informacji o objętości $\mathrm{KKCz}$ otrzymanego $\mathrm{z}$ syste$\mathrm{mu}$ Reveos bezpośrednio $\mathrm{z}$ urządzenia, w pracy zaprezentowano tylko wartość średnią objętości UKKCz obliczoną $z$ wyników kontroli jakości. Średnia objętość UKKCz otrzymanego $z$ systemu Reveos jest równa średniej objętości $\mathrm{KKCz}$ otrzymanego $z$ pras Compomat G5 $\mathrm{i}$ jest o $5 \%$ większa od średniej objętości $\mathrm{KKCz}$ otrzymanego $\mathrm{z}$ pras Optipress II. Po uwzględnieniu straty składnika na proces filtracji (ok. $30 \mathrm{ml}$ ) średnia objętość $\mathrm{KKCz}$ $Z$ systemu Reveos jest istotnie większa niz średnie objętości $\mathrm{KKCz} z$ pras. Johnson i wsp. równiez wykazali istotną statystycznie różnicę w objętości krwinek czerwonych pochodzących z porównywanych urządzeń Reveos i Optipres II [5]. Większa objętość $\mathrm{KKC} z$ otrzymanego $\mathrm{z}$ systemu Reveos jest $z$ wiązana $z$ brakiem straty krwinek czerwonych trafiających do kożuszka leukocytarno-płytkowego. Autorzy nie wykazali natomiast istotnych różnic w zawartości hemoglobiny, hematokrycie i liczbie leukocytów w analizowanych składnikach. Ponadto Johnson i inni ocenili, że metabolizm krwinek czerwonych otrzymanych $z$ systemu Reveos jest podobny do grupy kontrolnej [5]. Zaobserwowano tylko niewielkie różnice, na przykład niższe $\mathrm{pH}$ i niższe stężenie 2,3-DPG niż w grupie kontrolnej. Powszechnie wiadomo, $\dot{z}$ e wyczerpanie $2,3-\mathrm{DPG}$ powoduje wzrost zakwaszenia, a te dwa parametry są ze sobą powiązane [8]. Ponadto zaobserwowano większe zużycie glukozy w $\mathrm{KKC} z$ otrzymanym przy użyciu systemu Reveos w pierwszych dwóch tygodniach przechowywania. Autorzy tłumaczą to zjawisko większą liczbą krwinek czerwonych $\mathrm{w}$ składnikach otrzymywanych w systemie Reveos. Lindberg i wsp. zaobserwowali, że krwinki czerwone charakteryzują się hemolizą na poziomie $>0,8 \%$ po 42 dobach przechowywania.

W ostatnim etapie zebrano wyniki kontroli jakości dotyczące kożuszków leukocytarnopłytkowych i TKKP. Rozkład objętości i wartości indeksu płytkowego (PYI) TKKP uzyskanego za pomocą urządzenia Reveos przedstawiono w postaci histogramów na rycinie 3 . Średnia objętość TKKP wynosi 32,9 ml i jest 40-50\% mniejsza niż objętość kożuszków leukocytarno-płytkowych otrzymanych $z$ pras odpowiednio Compomat G5 i Optipress II. Mniejsza objętość TKKP oraz brak zanieczyszczenia krwinkami czerwonymi oznacza, że w przypadku rozdziału krwi w systemie Reveos więcej erytrocytów trafia do pojemnika $z \mathrm{KKC} z$. Tymczasowe koncentraty krwinek plytkowych charakteryzują się podobną średnią liczbą krwinek płytkowych co kożuszki leukocytarno-płytkowe. Johnson wykazał istotnie większą $(\mathrm{p}<0,05)$ liczbę krwinek płytkowych w zlewanych UKKP otrzymanych $z$ TKKP $\left(3,31 \times 10^{11}\right)$ w porównaniu ze składnikami otrzymanymi z kożuszków leukocytarno-płytkowych $\left(2,97 \times 10^{11}\right)$ [5]. Większa liczba krwinek płytkowych $w$ KKP $z$ TKKP jest związana $z$ tym, że w procedurze otrzymywania tego składnika nie ma dodatkowego wirowania i rozdziału na prasie. Innym powodem zwiększonej zawartości krwinek płytkowych jest możliwość wyboru do dalszej preparatyki tylko TKKP zawierających pożądaną ilość płytek krwi, oszacowaną przez urządzenie. Autorzy opisują, że parametry KKP uzyskane ze zlanych TKKP, takie jak: pH, zawartość glukozy, metabolizm mleczanów, ekspresja fosfatydyloseryny czy odpowiedź na szok hipotoniczny, są porównywalne $z$ parametrami UKKP otrzymywanymi innymi metodami. Zaobserwowano natomiast podwyższony poziom markerów aktywności płytek (CD62P i poziom cytokin). Sugeruje się, że na podwyższony poziom wyżej wymienionych markerów może mieć wpływ wykorzystanie podczas leukoredukcji innych filtrów czy przechowywanie UKKP w innych pojemnikach niż w przypadku UKKP $z$ grupy referencyjnej. W pracy opublikowanej w 2018 roku autorzy wykazali, że koncentraty krwi- 
nek płytkowych otrzymane $z$ TKKP nie różnią się w sposób istotny pod względem zawartości krwinek płytkowych i leukocytów od składników otrzymanych $z$ kożuszków leukocytarno-płytkowych przetworzonych metodą manualną i za pomocą urządzeń Orbisac [9]. Podobnie zadowalające rezultaty otrzymali Monge i wsp. badający jakość koncentratów płytkowych otrzymanych $z$ TKKP [10].

Automatyzacja procesu preparatyki krwi w celu uzyskania poszczególnych składników jest stale udoskonalana. Opisane w niniejszej pracy metody, pomimo różnic w sposobie wykonania samej procedury rozdziału, a w związku $z$ tym wykorzystania różnych technik i urządzeń, tylko w nieznacznym stopniu różnią się w zakresie jakości otrzymywanych składników. Należy zaznaczyć, że wszystkie składniki krwi otrzymywane $z$ wykorzystaniem opisanych wyżej metod spełniają rygorystyczne założenia kontroli jakości i z powodzeniem mogą być wykorzystywane w rutynowej pracy. System Reveos jako system najbardziej zautomatyzowany zyskuje tym samym przewagę nad dwuetapowymi metodami rozdziału KPK na składniki.

\section{Piśmiennictwo}

1. Heaton WA, Rebulla P, Pappalettera M, et al. A comparative analysis of different methods for routine blood component preparation. Transfus Med Rev. 1997; 11(2): 116-129, doi: 10.1053/ tm.1997.0110116, indexed in Pubmed: 9140171.
2. Högman CF, Eriksson L, Hedlund K, et al. The bottom and top system: a new technique for blood component preparation and storage. Vox Sang. 1988; 55(4): 211-217, indexed in Pubmed: 3064416.

3. Cid J, Magnano L, Lozano M. Automation of blood component preparation from whole blood collections. Vox Sang. 2014; 107(1): 10-18, doi: 10.1111/vox.12131, indexed in Pubmed: 24446859.

4. Obwieszenie Ministra Zdrowia z 6 marca 2019 r. w sprawie wymagań dobrej praktyki pobierania krwi i jej składników, badania, preparatyki, przechowywania, wydawania i transportu dla jednostek organizacyjnych publicznej służby krwi.

5. Johnson L, Winter KM, Kwok M, et al. Evaluation of the quality of blood components prepared using the Reveos automated blood processing system. Vox Sang. 2013; 105(3): 225-235, doi: 10.1111/vox.12051, indexed in Pubmed: 23713603.

6. Lagerberg JW, Salado-Jimena JA, Löf H, et al. Evaluation of the quality of blood components obtained after automated separation of whole blood by a new multiunit processor. Transfusion. 2013; 53(8): 1798-1807, doi: 10.1111/trf.12010, indexed in Pubmed: 23228178.

7. Bontekoe IJ, van der Meer PF, Mast G, et al. Separation of centrifuged whole blood and pooled buffy coats using the new CompoMat G5: 3 years experience. Vox Sang. 2014; 107(2): 140-147, doi: 10.1111/vox.12140, indexed in Pubmed: 24602034.

8. Hess JR. An update on solutions for red cel storage. Vox Sang. 2006; 91: 13-19.

9. Szykuła P, Stawicki K, Marciniak-Bielak D. System Reveos alternatywa w otrzymywaniu zlewanych koncentratów krwinek płytkowych. J Transf Med. 2017; 10: 141-148.

10. Monge J, Pérez Va, Azkarate An, et al. Quality of blood components using the Reveos automated blood processing system. Vox Sang. 2013; 105(1): 1-64. 